\title{
Pseudomonas anguilliseptica as a pathogen of salmonid fish in Finland
}

\author{
Tom Wiklund, Göran Bylund \\ Institute of Parasitology, Ảbo Akademi, Porthansg. 3, 20500 Åbo, Finland
}

\begin{abstract}
The bacterium Pseudomonas anguilliseptica Wakabayashi \& Egusa, originally described as a pathogen of eel in Japan, was isolated from diseased Atlantic salmon Salmo salar, sea trout Salmo trutta, rainbow trout Salmo gairdneri, and whitefish Coregonus sp. in Finland. Biochemical tests showed that the Finnish isolates are similar to the Japanese strains except for the Tween 80 reaction. Serologically, the Finnish strains of $P$. anguilliseptica are related to the Japanese isolates from ayu Plecoglossus altivelis. Gross signs in diseased salmonids were similar to those described for European eel, i.e. petechial haemorrhages in the skin, peritoneum, and liver. The effect of oxytetracycline therapy was disappointing in some of the outbreaks in salmonid fish. Apparently, alternative drugs will have to be employed to control the disease on salmonid farms.
\end{abstract}

\section{INTRODUCTION}

Pseudomonas anguilliseptica Wakabayashi \& Egusa was originally described as the bacterial causative agent of 'Sekiten-byo', or red spot disease, of pond-cultured Japanese eel Anguilla japonica Temminck \& Schlegel (Wakabayashi \& Egusa 1972). Later, the disease was also recorded from farmed European eel Anguilla anguilla (L.) in Japan and from Japanese eel in Taiwan (Kuo \& Kou 1978). In 1981 it was recorded for the first time from Europe, from European eel in Scotland (Nakai \& Muroga 1982, Stewart et al. 1983), and a few years later it was also reported in Danish eel farms (Mellergaard \& Dalsgaard 1986).

In Japan, the pathogen was subsequently isolated also from Black Sea bream Acanthopagrus schlegeli (Nakajima et al. 1983) and from ayu Plecoglossus altivelis (Schlegel) (Nakai et al. 1985).

In Finland, Pseudomonas anguilliseptica was identified as the causative agent of severe disease outbreaks in several species of farmed salmonid fish in 1986 (Wiklund \& Dalsgaard 1987).

The present paper gives some characteristics of the disease outbreaks and describes the biochemical and serological properties of the Finnish isolates of Pseudomonas anguilliseptica.

\section{Disease history}

Between May and November 1986 the disease was recorded from 5 brackish water fish farms in the Archipelago Sea on the SW coast of Finland. The causative agent was isolated during routine diagnostic work on fish with signs of a septicaemic disease. The affected fish were kept in net cages close to the sea shore. The salinity in the area varies from 5 to $6.5 \%$. The water temperature during the disease outbreaks was 15 to $18^{\circ} \mathrm{C}$.

Four fish species were affected: Atlantic salmon Salmo salar L., rainbow trout $S$. gairdneri Richardson, sea trout S. trutta L., and whitefish Coregonus sp. (Table 1). All fish affected were of the same age, 1+yr. Mortalities occurred on all farms, and reached a maximum (ca $50 \%$ ) in Atlantic salmon on one farm. Treatments with oxytetracycline at a dose-rate of $75 \mathrm{mg} \mathrm{kg}^{-1}$ for $8 \mathrm{~d}$ had limited effect.

\section{MATERIALS AND METHODS}

Bacteriology. Spleen, kidney, and liver were routinely sampled for bacterial isolation. Occasionally, sampling included the eyes, intestine, and ulcerated or haemorrhagic areas in the skin of the fish. The primary 
Table 1. Disease outbreaks caused by Pseudomonas anguilliseptica in different fish species and on different farms; Yes $=$ total mortality not recorded

\begin{tabular}{|llrrc|}
\hline Farm & \multicolumn{1}{c}{$\begin{array}{c}\text { Fish } \\
\text { species }\end{array}$} & $\begin{array}{c}\text { Date } \\
(1986)\end{array}$ & $\begin{array}{c}\text { Fish } \\
\text { age }\end{array}$ & Mortality \\
\hline A & Rainbow trout & 29 July & $1+$ & Yes \\
B & Atlantic salmon & 30 July & $1+$ & $50 \%$ \\
C & Whitefish & 4 Aug & $1+$ & $20 \%$ \\
D & Rainbow trout & 21 Aug & $1+$ & $5-6 \%$ \\
E & Sea trout & 12 Aug & $1+$ & Yes \\
& Rainbow trout & 13 Aug & $1+$ & Yes \\
& Whitefish & 1 Aug & $1+$ & Yes \\
\hline
\end{tabular}

bacterial isolations were made on blood agar ( $7 \%$ horse blood, $0.4 \% \mathrm{NaCl}$ ) (Orion Diagnostics) which was incubated at room temperature $\left(20\right.$ to $\left.25^{\circ} \mathrm{C}\right)$ for $1 \mathrm{wk}$ before being discarded.

Morphological studies were made on cells grown on nutrient agar (Difco Laboratories) supplemented with $0.1 \% \mathrm{MgCl}_{2}$. Motility was studied using the hanging drop technique on cells grown on the same medium. Motility was also observed by spreading growth in semi-solid agar tubes (SIM agar, Difco Laboratories), supplemented with $0.1 \% \mathrm{MgCl}_{2}$.

Growth ability was tested on the following media: brain heart infusion agar, tryptic soy agar, TCBS agar, MacConkey agar, and Pseudomonas isolation agar (Difco Laboratories).

Most basic tests were performed according to standard bacteriological techniques (MacFaddin 1983), using products from the Difco Laboratories. The final $\mathrm{NaCl}$ concentration in most media was $1 \%$.

Levan production tests were performed according to Hendrie \& Shewan (1979). Aesculin hydrolysis and lipase activity (Tween 80) were measured according to Cowan (1974). Kings A and B agar (E. Merck, Darmstadt) were used for the detection of pigment formation. $\mathrm{H}_{2} \mathrm{~S}$ and indole production were tested for on SIMmedium (Difco Laboratories). Simmon's citrate (Difco Laboratories) was used for the citrate utilization test. $\beta$-Galactosidase activity tests were performed with ONPG(o-nitrophenyl- $\beta$-D-galactopyranoside)-soaked paper discs. Acid production from carbohydrates was tested in peptone water with phenol red as the indicator. The following sugars and alcohols were used arabinose, dextrin, dulcitol, fructose, galactose, glucose, inositol, lactose, maltose, mannitol, mannose, rhamnose, salicin, sucrose, sorbitol, trehalose, and xylose. Salt tolerance was tested in nutrient broth containing $0,1,2,3,4$, or $5 \% \mathrm{NaCl}$ supplemented with $0.1 \% \mathrm{MgCl}_{2}$. These tests were all performed at $17^{\circ} \mathrm{C}$.

Bacterial growth at different temperatures was tested in nutrient broth with $1 \% \mathrm{NaCl}$ and $0.1 \% \mathrm{MgCl}_{2}$ at 4 to $5^{\circ} \mathrm{C}, 10^{\circ} \mathrm{C}, 30^{\circ} \mathrm{C}$, or $37^{\circ} \mathrm{C}$. Sensitivity of the isolates to antibiotics was examined using sensititre MIC (minimum inhibitory concentration) plates (Gibco) incubated at room temperature $\left(25.5\right.$ to $\left.26.5^{\circ} \mathrm{C}\right)$. The biochemical characteristics of the Finnish isolates were compared with those of the type strain NCMB 1949, originally isolated from Japanese eel (Nakajima et al. 1983).

Serology. All strains were serologically tested by the slide agglutination test using sera (diluted 1:5) made against the Japanese $P$. anguilliseptica strains ET-7601 and SH-82424, isolated from Japanese eel and ayu, respectively. The heat-labile antigen on the surface of the bacterial cells is different in these 2 strains (Nakai et al. 1985).

Histology. Histological studies were carried out on tissues from moribund trout and whitefish from the farms and on trout from the challenge tests. Samples of

Table 2. Pseudomonas anguilliseptica. Biochemical characteristics of Finnish isolates ( $n=16)$ compared with those of the type strain NCMB 1949

\begin{tabular}{|c|c|c|}
\hline Test & $\begin{array}{l}\text { Finnish } \\
\text { isolates }\end{array}$ & $\begin{array}{c}\text { NCMB } \\
1949\end{array}$ \\
\hline Gram & - & - \\
\hline Cytochrome oxidase & + & + \\
\hline Catalase & + & + \\
\hline O/F test & - & - \\
\hline Arginine dihydrolase & - & - \\
\hline Lysine decarboxylase & - & - \\
\hline Ornithine decarboxylase & - & - \\
\hline Indole production & - & - \\
\hline $\mathrm{H}_{2} \mathrm{~S}$ (SIM and TSI) & - & - \\
\hline Pigment (Kings A) & - & - \\
\hline Pigment (Kings $B$ ) & - & - \\
\hline Growth on TCBS agar & - & - \\
\hline Growth on MacConkey agar & + & + \\
\hline \multicolumn{3}{|l|}{ Growth on Pseudomonas } \\
\hline isolation agar & - & - \\
\hline Citrate utilization & $+(10 / 16)$ & + \\
\hline Tween 80 hydrolysis & - & + \\
\hline DNase & - & - \\
\hline Gelatin liquefaction & $+(3 / 16)$ & + \\
\hline Starch hydrolysis & - & - \\
\hline Haemolysis on blood agar & - & - \\
\hline Levan from sucrose & - & - \\
\hline Methyl red & - & - \\
\hline Voges Proskauer & - & - \\
\hline Urea & - & - \\
\hline Nitrate & - & - \\
\hline ONPG & - & - \\
\hline Aesculin hydrolysis & - & - \\
\hline Acid from carbohydrates & - & - \\
\hline Growth at $4-5^{\circ} \mathrm{C}$ & + & + \\
\hline Growth at $10^{\circ} \mathrm{C}$ & + & + \\
\hline Growth at $30^{\circ} \mathrm{C}$ & + & + \\
\hline Growth at $37^{\circ} \mathrm{C}$ & - & - \\
\hline Growth in $0 \% \mathrm{NaCl}$ & + & + \\
\hline Growth in $1 \% \mathrm{NaCl}$ & + & + \\
\hline Growth in $4 \% \mathrm{NaCl}$ & + & + \\
\hline Growth in $5 \% \mathrm{NaCl}$ & - & - \\
\hline
\end{tabular}




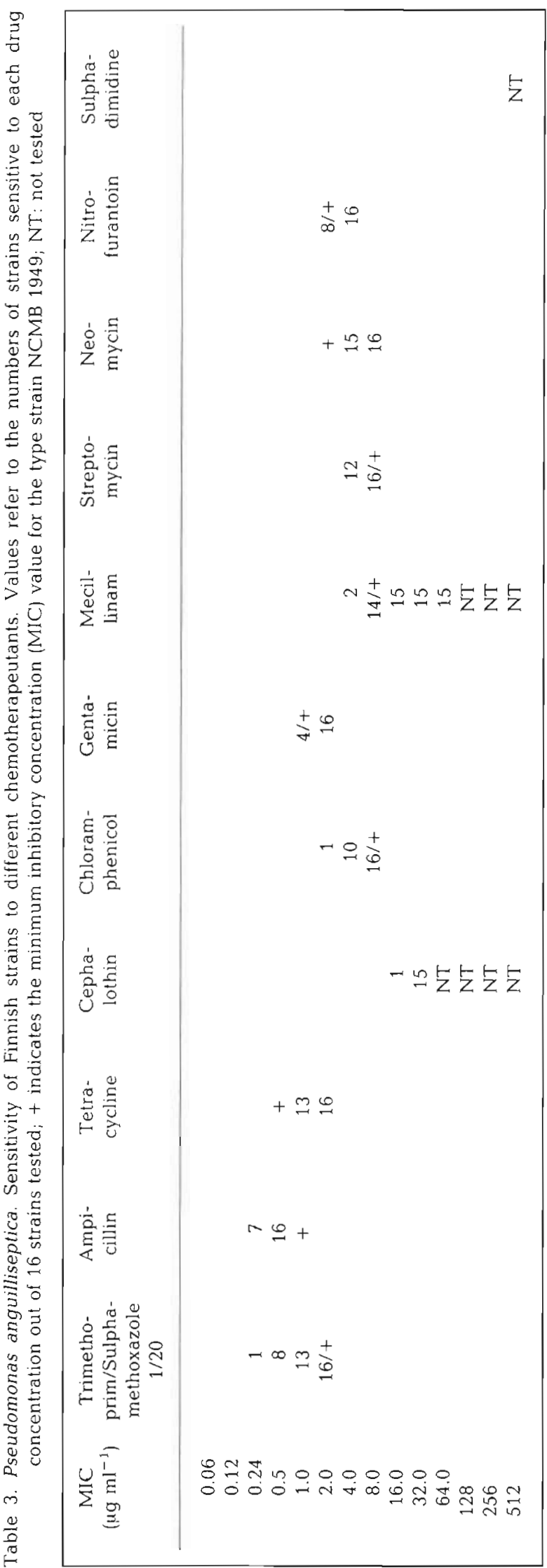

liver, kidney, and spleen were fixed in neutral buffered formalin. They were processed to yield 5 to $6 \mu \mathrm{m} \mathrm{sec-}$ tions and were stained with haematoxylin and eosin $(\mathrm{H} \& \mathrm{E})$.

Pathogenicity tests. To confirm the pathogenicity of the isolated organism, sea trout (25 to $175 \mathrm{~g}$ ) were challenged by intraperitoneal injection with $0.1 \mathrm{ml}$ of a washed cell suspension of the organism containing $0.6 \times 10^{4}, 0.6 \times 10^{7}$, or $0.6 \times 10^{9}$ cells. Cells for the challenge had been grown in nutrient broth $(1 \% \mathrm{NaCl}$ and $0.1 \% \mathrm{MgCl}_{2}$ ), and had been washed twice and suspended in $0.9 \% \mathrm{NaCl}$. The control group was injected with the saline solution. In each group 7 or 8 fish specimens were tested. The water temperature in the test tanks was 13 to $16^{\circ} \mathrm{C}$ and the fish were kept in dechlorinated tap water.

All dead or moribund fish and all fish still living on Day 14 post inoculation were subjected to bacteriological examination.

\section{RESULTS}

\section{Clinical signs}

Externally the disease was characterized by petechial haemorrhages in the skin (mainly on the ventral side of the body), in the mouth region, and the anal region. Haemorrhages at the fin bases occurred in rainbow trout. In all species, petechial haemorrhages were observed in the peritoneum and occasionally in the liver and adipose tissue of the visceral organs. The spleen was sometimes enlarged.

\section{Bacteriology}

Pure cultures of the bacterium were isolated from the kidney, liver, and spleen of fish with the clinical signs described. Occasionally, the bacterium was also isolated from the skin, intestine, eyes, and fin bases.

Based on the biochemical and serological tests performed (Table 2), the isolated bacterium was identified as Pseudomonas anguilliseptica Wakabayashi \& Egusa (Wiklund \& Dalsgaard 1987). This pathogen has never before been recorded from Finland, and its finding there represents the first record of its occurrence in trout and salmon.

The bacterium grew on basic agar media such as tryptic soy agar, brain heart infusion agar, and blood agar but it failed to grow on Pseudomonas isolation agar. After 3 to $4 \mathrm{~d}$ of incubation on tryptic soy agar the colonies were round, greyish, convex, entire, viscid, and $1 \mathrm{~mm}$ or less in diameter.

The bacterium was Gram-negative, motile with a 


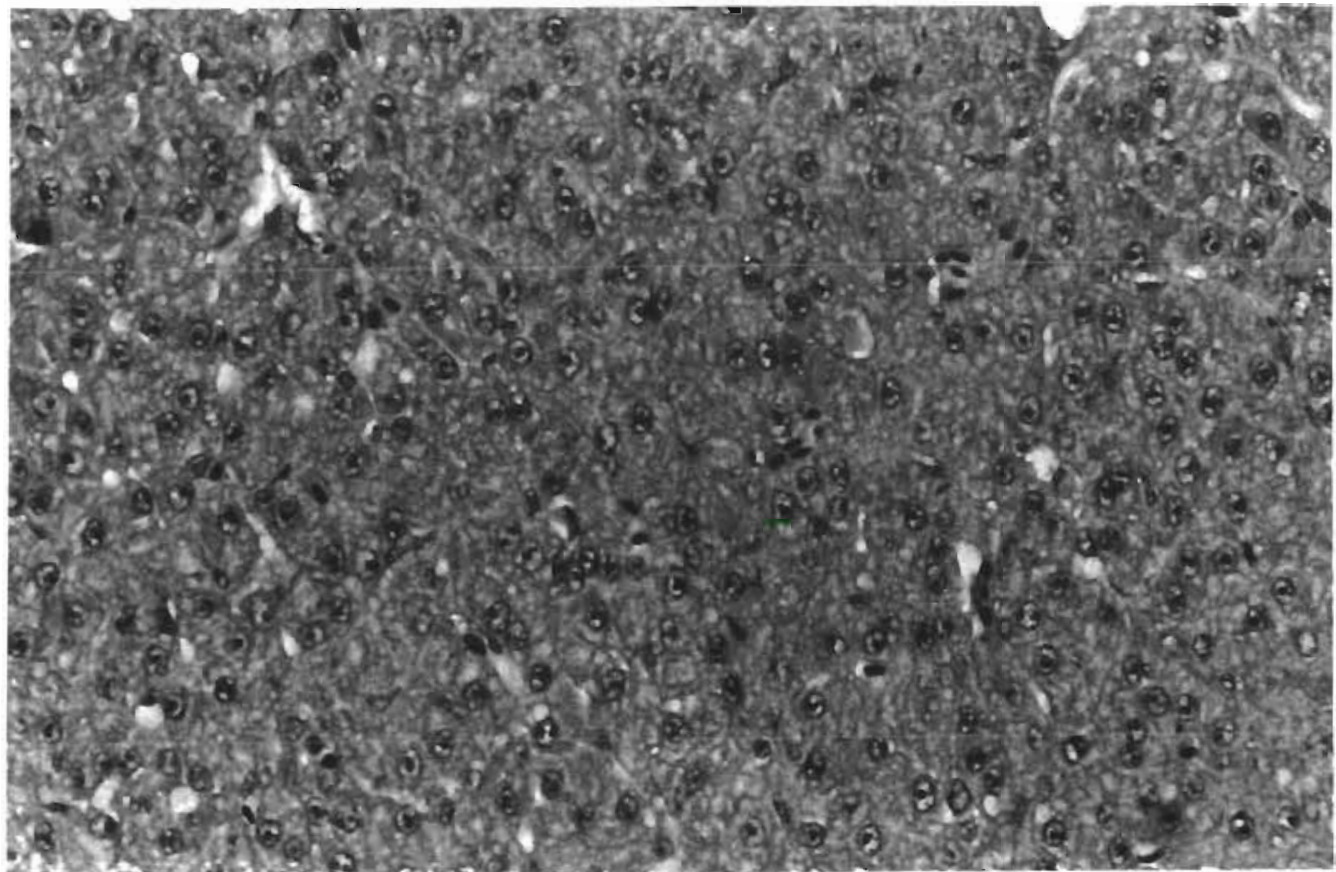

Fig. 1 Salmo trutta. Oedematous changes and finally complete disorganization of parenchymal cord structures in the liver of experimentally infected sea trout. $\left(H \& E_{1} \times 400\right)$

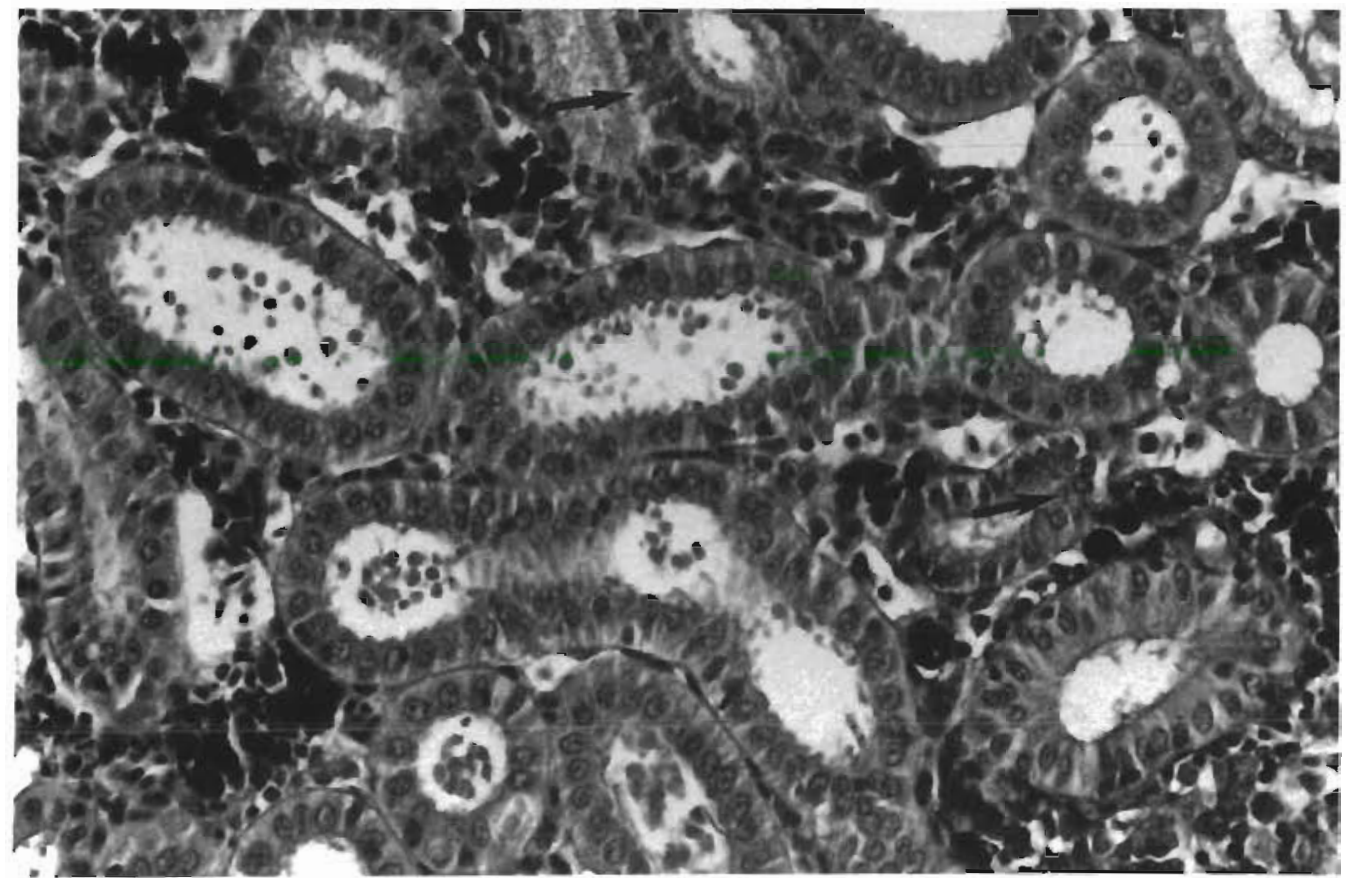

Fig. 2. Salmo trutta. Hyaline degeneration of tubular celis (arrow), accumulation of eosinophilic materials in tubuli, and massive deposits of melanin in the kidneys of experimentally infected sea trout $(\mathrm{H} \& \mathrm{E}, \times 400)$

single flagellum, rod-shaped $(0.5$ by 2 to $3 \mu \mathrm{m})$, cytochrome oxidase positive, and negative in Hugh-Leifsons O/F medium. The Finnish isolates $(n=16)$ gave biochemical reactions identical with those of the type strain NCMB 1949 except for Tween 80 hydrolysis (Table 2).

\section{Drug sensitivity}

The sensitivity tests (Table 3) showed a rather high MIC-value for tetracycline. Three of 16 strains tested had an MIC-value of $2.0 \mu \mathrm{g} \mathrm{ml} \mathrm{m}^{-1}$; the remaining 13 strains had an MIC-value of $1.0 \mu \mathrm{g} \mathrm{ml}^{-1}$ The type strain 
NCMB 1949 was more sensitive $\left(0.48 \mu \mathrm{g} \mathrm{ml}^{-1}\right)$ to tetracycline.

The substances that proved most active against the pathogen were ampicillin and trimethoprim/ sulphametoxazole with MIC-values of $0.24 \mu \mathrm{g} \mathrm{ml}^{-1}$ and $0.24 / 4.74 \mu \mathrm{g} \mathrm{ml}^{-1}$, respectively. All strains tested, including the type strain, were resistant to sulphadimidine.

\section{Serology}

All the strains tested agglutinated with the antisera made against the Japanese strain SH-82424 from ayu but not with the antisera made against the strain ET7601 from eel.

\section{Histopathology}

Histopathological changes were observed in trout and whitefish from the farms and especially in the fish from the challenge tests (Figs. 1 and 2). These findings included oedematous changes in the liver with disorganization of the parenchymal cord structures, cloudy swelling of the hepatic cells, and areas of liver cell necrosis (pycnosis). Perivascular cell infiltrations occurred. Oedematous changes in the kidney involved the glomeruli as well as the tubuli, and were sometimes associated with detachment of the tubular epithelium. Accumulation of hyaline granules occurred in the tubular cells, and eosinophilic materials were observed in the tubular lumen in fish challenged with the highest concentration of bacteria. Exhaustion of haematopoietic tissues was seen in most fish studied.

\section{Challenge tests}

All fish in Group I injected with the highest concentration of bacteria $\left(0.6 \times 10^{9}\right.$ cells per fish) died within 7 to $9 \mathrm{~d}$ of challenge. Pseudomonas anguilliseptica was reisolated from visceral organs of all dead fish (Table 4$)$. In Group II $\left(0.6 \times 10^{7}\right.$ cells) 7 of 8 challenged fish died within 6 to $10 \mathrm{~d}$ but $P$. anguilliseptica was reisolated from only 3 specimens. However, the results from this group as well as from Group III $\left(0.6 \times 10^{4}\right.$ cells per fish) and Group IV (control) were of questionable significance due to concomitant infections with Aeromonas hydrophila and Saprolegnia sp.

\section{DISCUSSION}

Pseudomonas anguilliseptica infections have caused high mortalities on Japanese eel farms since the disease was first recorded in 1971 (Muroga \& Nakajima 1981). Likewise, in the Finnish outbreaks some salmonid farms experienced heavy losses, with mortalities of up to $50 \%$. The results indicate a considerable variation in the susceptibility of different salmonid fish species to the disease. Of the species affected, Atlantic salmon and whitefish suffered the highest mortalities while rainbow trout seemed to be rather resistant to the infection. Experimental results on the variation in the susceptibility to the disease among different fish species were reported with the Japanese strains. The strains $\left(\mathrm{K}^{+}\right.$serotype) isolated from diseased eel in Japan were non-pathogenic for rainbow trout, amago Oncorhyncus rhodurus f. macrostomus, kokanee salmon O. nerka f. adonis, and iwana Salvelinus pluvius (Uno 1976). They showed low pathogenicity for carp Cyprinus carpio, crucian carp Carassius carassius, and goldfish Carassius auratus (Muroga et al. 1975), but were relatively highly pathogenic for Japanese eel (Nakai 1985) ayu, loach Misgurnus anguillicaudatus, and bluegill sunfish Lepomis macrochirus (Muroga et al. 1975).

The clinical signs in the diseased salmonids were similar to those described from European eel, i.e. petechial haemorrhages in the skin as well as in peritoneum and liver (Wakabayashi \& Egusa 1972, Ellis et al. 1983, Mellergaard \& Dalsgaard 1986). Ellis et al. (1983) also noted that the kidneys in affected European eel were soft and sometimes liquefied. Pronounced macroscopic changes were not observed in the kidneys of the salmonids in the present work but the histopathology showed that the kidneys were severely affected.

Table 4. Salmo trutta. Challenge tests with Pseudomonas anguilliseptica ( $\mathrm{Pa}$ ) on sea trout

\begin{tabular}{|ccccc|}
\hline $\begin{array}{c}\text { Fish group } \\
\text { no. }\end{array}$ & $\begin{array}{c}\text { Inj. dose } \\
\text { (cells fish }\end{array}$ & $\begin{array}{c}\text { Time to } \\
\text { mortality }\end{array}$ & $\begin{array}{c}\text { No. of fish dead/ } \\
\text { no. fish tested }\end{array}$ & $\begin{array}{c}\text { No. dead fish } \\
\text { yielding Pa }\end{array}$ \\
\hline I & $0.6 \times 10^{9}$ & $7-9 \mathrm{~d}$ & $7 / 7$ & $7 / 7$ \\
II & $0.6 \times 10^{7}$ & $6-10 \mathrm{~d}$ & $7 / 8$ & $3 / 7$ \\
III & $0.6 \times 10^{4}$ & $14 \mathrm{~d}$ & $2 / 7$ & $0 / 7$ \\
IV & control & $14 \mathrm{~d}$ & $0 / 7$ \\
& (physiol. sal) & & & \\
\hline
\end{tabular}


The biochemical tests showed that the Finnish isolates differed in some respects from the Japanese strains: the Tween 80 reaction was negative for our isolates but was positive for the Japanese isolates from eel (Nakai \& Muroga 1982) and ayu (Nakai et al. 1985) and for the type strain NCMB 1949. Some of the Finnish strains showed a positive gelatinase reaction like the type strain but the gelatinase test was negative for the strains from ayu (Nakai et al. 1985). Growth in $4 \%$ $\mathrm{NaCl}$ was positive for all Finnish isolates and for the type strain, but was negative for the ayu isolates (Nakai et al. 1985) and some eel isolates (Nakai \& Muroga 1982).

The effect of oxytetracycline therapy was disappointing in some of the Finnish outbreaks. Apparently this was due to the rather low sensitivity of Pseudomonas anguilliseptica to the drug. Chemotherapy was ineffective in Japanese eel, because 'Sekiten-byo' prevailed mostly in early spring when eel would not take feed due to low water temperatures (Muroga \& Nakajima 1981). In eel the disease was controlled by raising the water temperature above $27^{\circ} \mathrm{C}$ or by using fresh water instead of brackish water. Such procedures cannot, however, be applied in salmonid farming. Apparently, drugs other than oxytetracycline have to be employed to control the disease on salmonid farms. Jo (1978) found that oxolinic acid was effective against the disease. The sensitivity of the pathogen to this drug was not tested in our laboratory.

On the basis of the heat-labile surface antigen $(\mathrm{K})$ carried by the bacterium, 3 different Pseudomonas anguilliseptica serotypes have been distinguished among the Japanese strains: K-lacking $\left(\mathrm{K}^{-}\right)$and $\mathrm{K}$ possessing $\left(\mathrm{K}^{+}\right)$serotypes isolated from eels (Nakai et al. 1981), and a $\mathrm{K}^{+}$-serotype isolated from ayu (Nakai et al. 1985). Our slide agglutination tests showed that the Finnish strains of $P$. anguilliseptica belong to the $\mathrm{K}^{+}$ serotype isolated from ayu. As stated above, however, there were some differences in biochemical characters between the Finnish isolates and the ayu isolates.

Nakai et al. (1981) stated that Pseudomonas anguilliseptica from eel may be rapidly identified by slide agglutination, although slight cross-reactions occurred with some strains of Pseudomonas sp., P. putida, and Vibrio anguillarum. They recommended the use of diluted antisera (1:10). Toranzo et al. (1987) also found that diluted antisera (1:5) prepared against $P$. anguilliseptica isolated from eels did not cross-react with other pathogenic Pseudomonas strains ( $P$. fluorescens and $P$. aeruginosa).

The reason for the sudden occurrence of Pseudomonas anguilliseptica on several fish farms on the Finnish sea coast is difficult to explain. It is possible that the pathogen has always been present but was overlooked because Pseudomonas infections tended to be diagnosed only to the generic level (Pseudomonas sp.). Subsequent work in our laboratory clearly shows that the optimum growth conditions for this pathogen (salinity, temperature) correspond well to those prevailing in the Baltic area. Thus $P$. anguilliseptica has to be considered a potential hazard to the salmonid farming now rapidly expanding in the Baltic.

Acknowledgements. We are grateful to Dr T Nakai, Fish Disease Lab., Hiroshima University, Japan for supplying the antisera, Mrs Henna-Riitta Lehti for skilful technical assistance, and Salmon Research Inc. for supplying facilities.

\section{LITERATURE CITED}

Cowan, S. T. (1974). Cowan and Steel's manual for the identification of medical bacteria, 2nd edn. Cambridge Univ. Press, Cambridge

Ellis, A. E., Dear, G., Stewart, D. J. (1983). Histopathology of 'Sekiten-byo' caused by Pseudomonas anguilliseptica in the European eel, Anguilla anguilla L., in Scotland. J. Fish Dis. 6: $77-79$

Hendrie, M. S., Shewan, J. M. (1979). The identification of pseudomonads. In: Skinner, F. A., Lovelock, D. W. (eds.) Identification methods for microbiologists, 2nd edn. Academic Press, London, p. 1-14

Jo, Y (1978). Therapeutic experiments on red spot disease. Fish Pathol. 13: 41-42

Kuo, S.-K., Kou, G.-H. (1978). Pseudomonas anguilliseptica isolated from red spot disease of pond-cultured eel, Anguilla japonica. Rep. Inst. Fish. Biol. Min. Econ. Aff. Nat. Taiwan Univ. 3: 19-23

MacFaddin, J. F. (1983). Biochernical tests for identification of medical bacteria, 2nd edn. Williams \& Wilkins, Baltimore

Mellergaard, S., Dalsgaard, I. (1986). Håndbog i Ålesygdomme. Danmarks Fiskeri-og Havundersøgelser rapport no. $293,46 \mathrm{pp}$.

Muroga, K., Jo, Y., Sawada, T (1975). Studies on red spot disease of pond-cultured eels - II. Pathogenicity of the causative bacterium, Pseudomonas anguilliseptica. Fish Pathol. 9: 107-114

Muroga, K., Nakajima, K. (1981). Red spot disease of cultured eels - methods for artificial infection. Fish Pathol. 15: $315-318$

Nakai, T. (1985). Resistance of Pseudomonas anguilliseptica to bactericidal action of fish serum. Bull. Jap. Soc. scient. Fish. 51. 1431-1436

Nakai, T., Hanada, H., Muroga, K. (1985). First records of Pseudomonas anguilliseptica infection in cultured ayu, Plecoglossus altivelis. Fish Pathol. 20: 481-484

Nakai, T., Muroga, K. (1982). Pseudomonas anguilliseptica isolated from European eels (Anguilla anguilla) in ScotIand. Fish Pathol. 17. 147-150

Nakai, T., Muroga, K., Wakabayashi, H. (1981). Serological properties of Pseudomonas anguiliseptica in agglutination. Bull. Jap. Soc. scient. Fish. 47: 699-703

Nakajima, K., Muroga, K., Hancock, R. (1983). Comparıson of fatty acid, protein and serological properties distinguishing outer membranes of Pseudomonas anguilliseptica strains from those of fish pathogens and other pseudomonads. Int. J. syst. Bact. 33: 1-8

Stewart, D. J., Woldemariam, K., Dear, G., Mochaba, F. (1983). An outbreak of 'Sekiten-byo' among cultured European eels, Anguilla anguilla L., in Scotland. J. Fish Dis. 6: 75-76 
Toranzo, A., Baya, A., Roberson, B., Barja, J,, Grimes, D., Hetrick, F. (1987). Specificity of slide agglutination test for detecting bacterial fish pathogens. Aquaculture 61: 81-97

Uno, M. (1976). Experimental pathogenicity of Aeromonas salmonicida, Vibrio anguillarum and Pseudomonas anguilliseptica for iwana and other trout. Fish Pathol. 11: 5-9

Wakabayashi, H., Egusa, S. (1972). Characteristics of a Pseudomonas sp. from an epizootic of pond-cultured eels

Responsible Subject Editor: Dr T Evelyn, Nanaimo, B.C., Canada
(Anguilla japonica). Bull. Japan. Soc. scient. Fish. 38: $577-587$

Wiklund, T., Dalsgaard, I. (1987). Disease outbreaks caused by Pseudomonas anguilliseptica in Finnish fish farms. In: Stenmark, A., Malmberg, G. (eds.) Parasites and diseases in natural waters and aquaculture in nordic countries. Swedish Museum of Natural History, Stockholm, p. 131 (Abstract)

Manuscript first received: April 28, 1989

Revised version accepted: November 16, 1989 